\title{
Dopamine Receptors Differentially Control Binge Alcohol Drinking-Mediated Synaptic Plasticity of the Core Nucleus Accumbens Direct and Indirect Pathways
}

\author{
Xincai Ji, @Sucharita Saha, Jenya Kolpakova, Melissa Guildford, Andrew R. Tapper, and @Gilles E. Martin \\ Brudnick Neuropsychiatric Research Institute, Department of Psychiatry, University of Massachusetts Medical School, Worcester, Massachusetts 01604
}

Binge alcohol drinking, a behavior characterized by rapid repeated alcohol intake, is most prevalent in young adults and is a risk factor for excessive alcohol consumption and alcohol dependence. Although the alteration of synaptic plasticity is thought to contribute to this behavior, there is currently little evidence that this is the case. We used drinking in the dark (DID) as a model of binge alcohol drinking to assess its effects on spike timing-dependent plasticity (STDP) in medium spiny neurons (MSNs) of the core nucleus accumbens (NAc) by combining patch-clamp recordings with calcium imaging and optogenetics. After 2 weeks of daily alcohol binges, synaptic plasticity was profoundly altered. STDP in MSNs expressing dopamine D1 receptors shifted from spike-timing-dependent long-term depression (tLTD), the predominant form of plasticity in naive male mice, to spike-timing-dependent long-term potentiation (tLTP) in DID mice, an effect that was totally reversed in the presence of $4 \mu \mathrm{MSCH} 23390$, a dopamine D1 receptor antagonist. In MSNs presumably expressing dopamine D2 receptors, tLTP, the main form of plasticity in naive mice, was inhibited in DID mice. Interestingly, $1 \mu \mathrm{M}$ sulpiride, a D2 receptor antagonist, restored tLTP. Although we observed no alterations of AMPA and NMDA receptor properties, we found that the AMPA/NMDA ratio increased at cortical and amygdaloid inputs but not at hippocampal inputs. Also, DID effects on STDP were accompanied by lower dendritic calcium transients. These data suggest that the role of dopamine in mediating the effects of binge alcohol drinking on synaptic plasticity of NAc MSNs differs markedly whether these neurons belong to the direct or indirect pathways.

Key words: binge alcohol drinking; dopamine; nucleus accumbens; optogenetics; spike timing-dependent plasticity

\section{Significance Statement}

We examined the relationship between binge alcohol drinking and spike timing-dependent plasticity in nucleus accumbens (NAc) neurons. We found that repeated drinking bouts modulate differently synaptic plasticity in medium spiny neurons of the accumbens direct and indirect pathways. While timing-dependent long-term depression switches to long-term potentiation (LTP) in the former, timing-dependent LTP is inhibited in the latter. These effects are not accompanied by changes in AMPA and NMDA receptor properties at cortical, amygdaloid, and hippocampal synapses. Interestingly, dopamine D1 and D2 receptor antagonists have opposite effects on plasticity. Our data show that whether core NAc medium spiny neurons belong to the direct or indirect pathways determines the form of spike timing-dependent plasticity (STDP), the manner by which STDP responds to binge alcohol drinking, and its sensitivity to dopamine receptor antagonists.

\section{Introduction}

As originally described by Tomsovic (1974), binge alcohol drinking is defined as repeated periods of heavy drinking, followed by

\footnotetext{
Received Dec. 15, 2016; revised April 24, 2017; accepted April 25, 2017.

Author contributions: X.J. and G.E.M. designed research; X.J., S.S., J.K., and M.G. performed research; A.R.T. contributed unpublished reagents/analytic tools; X.J. and S.S. analyzed data; A.R.T. and G.E.M. wrote the paper.

This work was supported by National Institute of Alcohol Abuse and Addiction Grants AA020501 (G.E.M), AA017656 (A.R.T), and AA022567 (M.G.); and by the Integrative Neuroscience Initiative on Alcoholism (INIA-West; G.E.M.).

The authors declare no competing financial interests.

Correspondence should be addressed to Gilles E. Martin, University of Massachusetts Medical School, The Brudnick Neuropsychiatric Research Institute, Department of Psychiatry; 303 Belmont Street, Worcester, MA 01604. E-mail: gilles.martin@umassmed.edu.
}

periods of abstinence. In a recent attempt to standardize the study of binge alcohol drinking, an updated definition stipulates that binge alcohol drinking brings blood alcohol levels to $\geq 0.08 \%$, which typically corresponds to consuming five or more drinks (male) or four or more drinks (female) in $\sim 2 \mathrm{~h}$ (National Institute of Alcohol Abuse and Alcoholism, 2004). This drinking pattern has been studied mostly in young adult populations (e.g., college students) as they represent by far the largest group affected by this behavior (Naimi et al., 2003). Not only does heavy binge alcohol drinking potentially lead to destructive behaviors 
like suicide, insomnia, drunk driving (Wechsler et al., 1994), and cognitive deficits (Duka et al., 2004), but it is also recognized as being the precursor to long-term alcohol-related problems like sleep disorders, stroke, and social anxiety (Townshend and Duka, 2002; Weissenborn and Duka, 2003; Hartley et al., 2004). Importantly, binge drinkers, contrary to light drinkers, typically display a strong response to early euphoric effects but are less sensitive to the sedative effects of alcohol, indicative of a predisposition for the development of alcohol addiction (Schuckit, 1994; Schuckit et al., 2008).

While binge alcohol drinking has been studied extensively from a behavioral and epidemiological perspective, there is comparatively very little known about how it impacts neurological processes. To date, a number of studies have shown that binge alcohol drinking alters the function of a number of ionotropic (e.g., AMPA) and metabotropic (e.g., mGluR1 and 5) glutamate receptors (Cozzoli et al., 2009; Lum et al., 2014; Agoglia et al., 2015; Silvestre de Ferron et al., 2015), possibly through protein kinases (Gibb et al., 2011; Cozzoli et al., 2016). This has led some to propose that synaptic plasticity may be one of the binge alcohol drinking targets (Stephens and Duka, 2008). In a recent study (Silvestre de Ferron et al., 2015), two consecutive ethanol "binges" in the hippocampi of adolescent rats reversibly abolished long-term depression (LTD) and evoked cognitive deficits via a shortlasting, repeated blockade of NMDA receptors, seemingly contradicting two earlier reports (Roberto et al., 2002; Stephens et al., 2005) showing an inhibitory effect of binge alcohol drinking on long-term potentiation (LTP) in the same brain region. Yet, whether and how binge alcohol drinking modulates synaptic plasticity, and by extension memory formation in other brain regions targeted by drugs of abuse, remains unknown. To address this problem, we examined synaptic plasticity in medium spiny neurons (MSNs) of the core NAc, a brain region known for its central role in mediating the rewarding properties of all drugs of abuse, including alcohol (Koob, 1996). In light of a recent report showing that ethanol blocked conventional LTD in NAc MSNs in a different model of chronic alcohol exposure [i.e., chronic intermittent ethanol exposure (CIE); Renteria et al., 2017], we wondered whether drinking in the dark (DID), a model of shorter ethanol exposure, also regulates spike timing-dependent plasticity (STDP). Additionally, Shen et al. (2008), having reported that dopamine receptors differentially modulate STDP of the dorsal striatum direct and indirect pathways, we hypothesize that they also differentially alter the response of these pathways to binge alcohol drinking in core NAc MSNs. Our data show that whether core NAc MSNs belong to the direct or indirect pathways determines the form of STDP, the manner by which STDP responds to binge alcohol drinking, and its sensitivity to dopamine receptor antagonists.

\section{Materials and Methods}

All experiments were performed on male C57BL/6J and D1r.Td-tomato mice. All mice were handled according to the American Association for the Accreditation of Laboratory Animal Care guidelines. The protocol was approved by the Institutional Animal Care and Use Committee of the University of Massachusetts Medical School. Mice were maintained at constant temperature and humidity with a $12 \mathrm{~h}$ light/dark cycle. Water and food were provided ad libitum.

Mice surgeries. We injected 21- to 24-d-old (10-15 g) C57BL/6J mice with adeno-associated virus containing pAAV9-CaMKIIa-hChR2(H134R)EYFP (a gift from Dr. K. Deisseroth, Stanford University, Palo Alto, CA) bilaterally $(0.8 \mu \mathrm{l}$ in each side) using a Hamilton syringe with a 2-inchlong 26 ga needle stereotaxically placed into the prelimbic PFCx (anteroposterior, $+1.85 \mathrm{~mm}$ from bregma; mediolateral, $+0.3 \mathrm{~mm}$ from bregma; ventral, $-2.9 \mathrm{~mm}$ from skull surface), the amygdala basal nucleus (anteroposterior, $-0.9 \mathrm{~mm}$ from bregma; mediolateral, $+2.8 \mathrm{~mm}$ from bregma; ventral, $-5 \mathrm{~mm}$ from skull surface), or the ventral hippocampus (anteroposterior, $-3.3 \mathrm{~mm}$ from bregma; mediolateral, 2.8 $\mathrm{mm}$ from bregma; ventral, $-4.8 \mathrm{~mm}$ from skull surface). Virus injections in the PFCx, amygdala, and hippocampus were performed on different mice. The injector was left in place for $5 \mathrm{~min}$, raised $1 \mathrm{~mm}$, and left for an additional $5 \mathrm{~min}$ before being removed. We returned mice to their home cages for $21 \mathrm{~d}$ before performing electrophysiological experiments.

Drinking in the dark. Two days following brain viral injections, mice were allowed to adapt to the reverse light/dark cycle ( $12 \mathrm{~h}$ cycle, off at 8:00 A.M., on at 8:00 P.M.) for 1 week, at which point they were single housed. They were given water bottles with sipper tubes before the experiment to habituate them and reduce the novelty effect once the ethanol bottle, containing a similar sipper tube, was presented. The total habituation time for the reverse cycle was 2 weeks before the experiment began. The experiment started $2 \mathrm{~h}$ into the dark phase of the cycle and lasted for $2 \mathrm{~h}$ (Rhodes et al., 2005; Hendrickson et al., 2009). At the start of the experiment, each water bottle was removed and replaced with a preweighed $50 \mathrm{ml}$ conical tube containing $20 \%$ ethanol (or 10\% sucrose for control mice) with a rubber stopper and double-ball bearing sipper tube. The mice were allowed to drink for $2 \mathrm{~h}$, and then the ethanol bottles were removed, weighed, and the water bottles were replaced. Ethanol consumed was measured as grams of ethanol divided by mouse body weight in kilograms. This protocol was repeated $5 \mathrm{~d}$ /week with $2 \mathrm{~d}$ off (water only) after each $5 \mathrm{~d}$ span. Drip controls were used to account for evaporation and dripping, and experimental bottle weights were corrected using the control values. On average, mice steadily increased their consumption of alcohol before reaching a maximum $\sim 7 \mathrm{~g} / \mathrm{kg} 20 \%$ EtOH per drinking session at the end of a 2 week period (Fig. $1 D ; n=15$ ). All electrophysiological recordings were performed $24 \mathrm{~h}$ after the last drinking bout during the third week.

Slice preparation. To prepare coronal slices from fresh brain tissue, we rapidly removed and transferred the brain in a cold $\left(\sim 0.5^{\circ} \mathrm{C}\right)$, oxygenated $\left(95 \% \mathrm{O}_{2}\right.$ and $\left.5 \% \mathrm{CO}_{2}\right)$ solution with the following composition (in mM): $95 \mathrm{~N}$-methyl-D-glucamine (NMDG), 2 thiourea, $5 \mathrm{Na}^{+}$-ascorbate, and $3 \mathrm{Na}^{+}$-pyruvate into cut slices $(300 \mu \mathrm{m})$ with a Vibroslicer (VT1200, Leica MicroInstrutments). Slices were immediately transferred in an incubation chamber and left to recuperate in a NMDG-based solution for $22 \mathrm{~min}$ at $32^{\circ} \mathrm{C}$ before being moved into a chamber containing an artificial CSF (ACSF) as follows (in mM): $126 \mathrm{NaCl}, 2.5 \mathrm{KCl}, \mathrm{NaH}_{2} \mathrm{PO}_{4} \cdot \mathrm{H}_{2} \mathrm{O}, 1$ $\mathrm{MgCl}_{2}, 2 \mathrm{CaCl}_{2}, 26 \mathrm{NaHCO}_{3}$, and $10 \mathrm{D}$-glucose, at room temperature. Slices were left in this chamber for at least $1 \mathrm{~h}$ before being placed in a recording chamber and perfused with ACSF at a constant rate of 2-3 $\mathrm{ml} / \mathrm{min}$ at room temperature $\left(\sim 21^{\circ} \mathrm{C}\right)$. We visualized neurons in infrared differential interference contrast $(60 \times$, infrared differential interference contrast) videomicroscopy using a fully motorized upright microscope (Scientifica).

Electrophysiology. We performed whole-cell patch-clamp recordings in the absence of GABA receptor antagonists as described previously (Ji et al., 2015). Briefly, we filled borosilicate glass electrodes (outer diameter, $1.5 \mathrm{~mm}$; resistance, $4-6 \mathrm{M} \Omega$ ) with an internal solution containing the following (in mM): $120 \mathrm{~K}$-methanesulfonate; $20 \mathrm{KCl} ; 10 \mathrm{HEPES} ; 2 \mathrm{~K}_{2} \mathrm{ATP}$, $2 \mathrm{~K}_{2} \mathrm{GTP}$, and 12 phosphocreatine. We replaced K-methanesulfonate with Cs-methanesulfonate and added $1 \mu \mathrm{M}$ QX-314 in the pipette solution when recording AMPA and NMDA EPSCs. Following seal rupture, series resistance (Rs), typically ranging between 10 and $20 \mathrm{M} \Omega$, was fully compensated in current-clamp recording mode, and periodically monitored throughout recording sessions. Recordings with Rs changes $>20 \%$ were rejected. We acquired voltage and current traces in whole-cell patch clamp with an EPC10 amplifier (HEKA Elektronik). We sampled and filtered voltage and current traces acquired with PatchMaster version 2.15 software (HEKA Elektronik) at $10 \mathrm{kHz}$ ( $20 \mathrm{kHz}$ during induction of plasticity) and $2 \mathrm{kHz}$, respectively. We subsequently analyzed all traces off-line using FitMaster 2.15 software (HEKA Electronik). We evoked EPSPs by placing a concentric bipolar stimulating electrode in proximity to the recording patch pipette. To generate synaptic plasticity, we paired postsynaptic action potential (AP; evoked with a $5 \mathrm{~ms} / 700-800 \mathrm{pA}$ depolarizing pulse) and electrically- and optogenetically-driven EPSPs with 

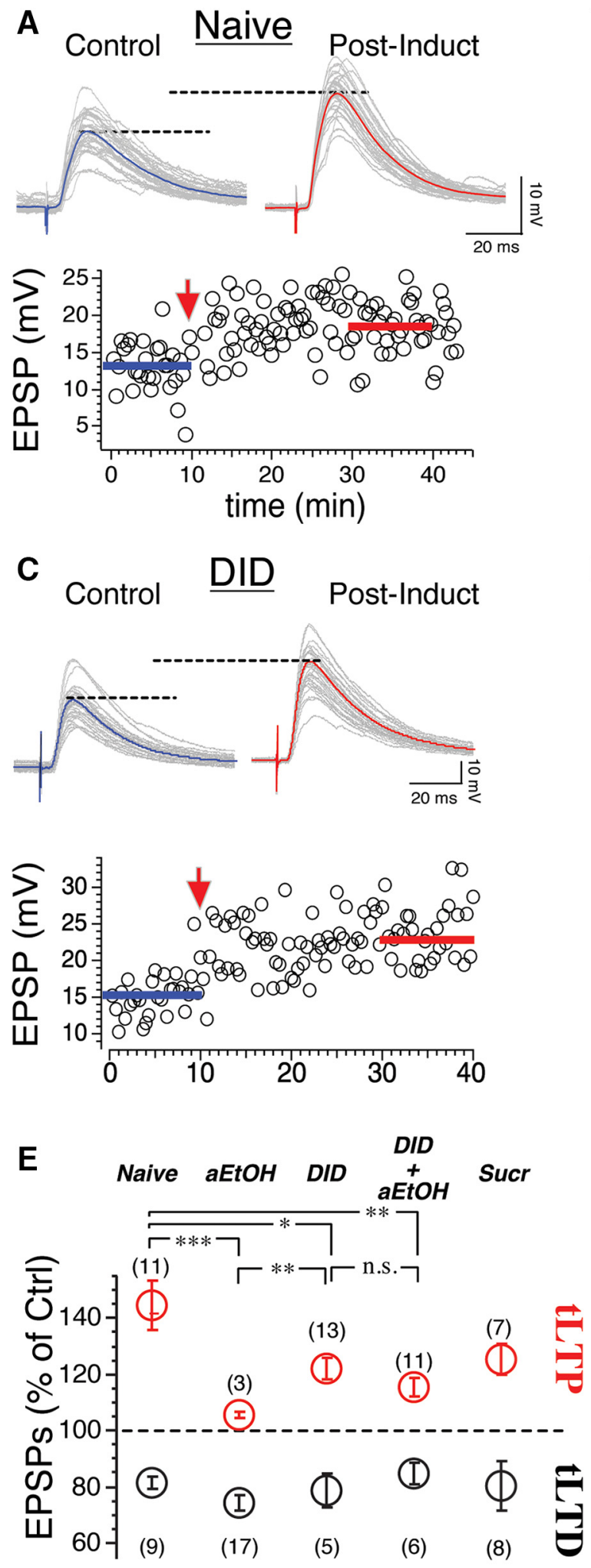
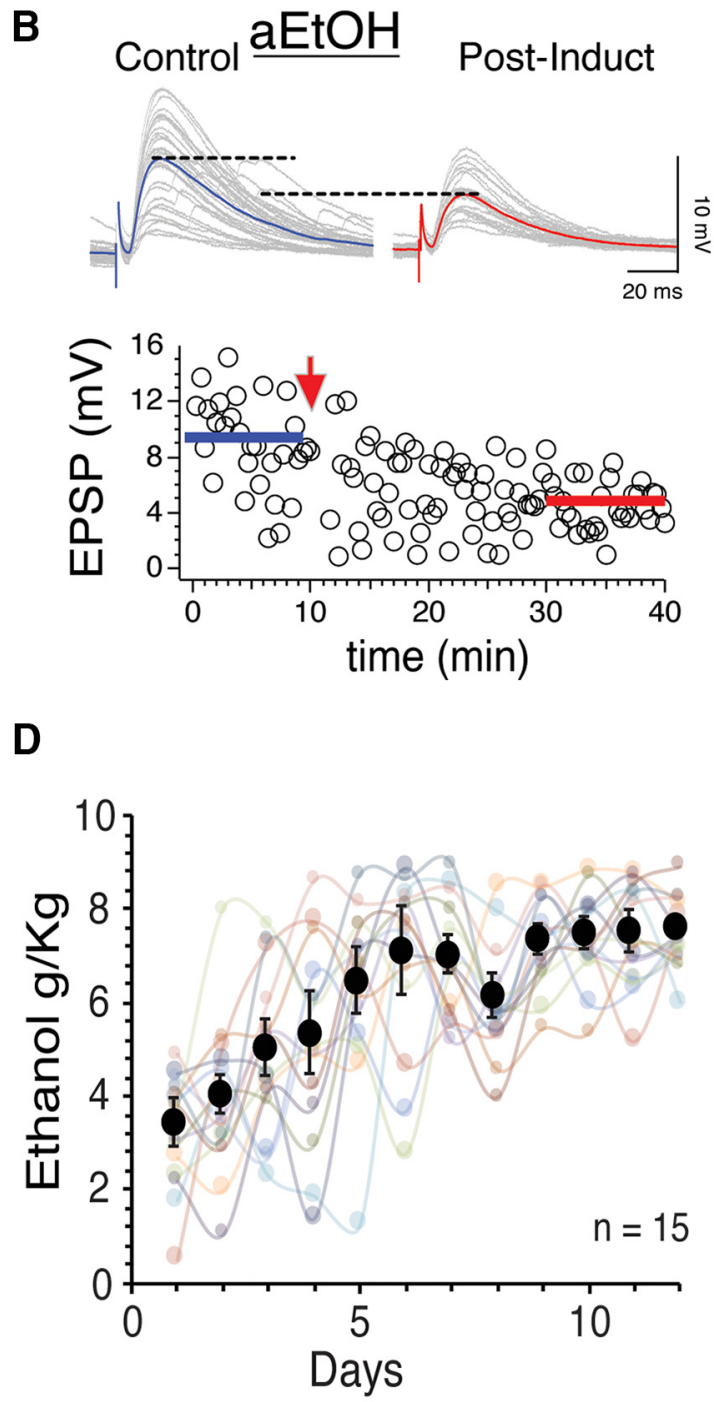

$\mathbf{F}$

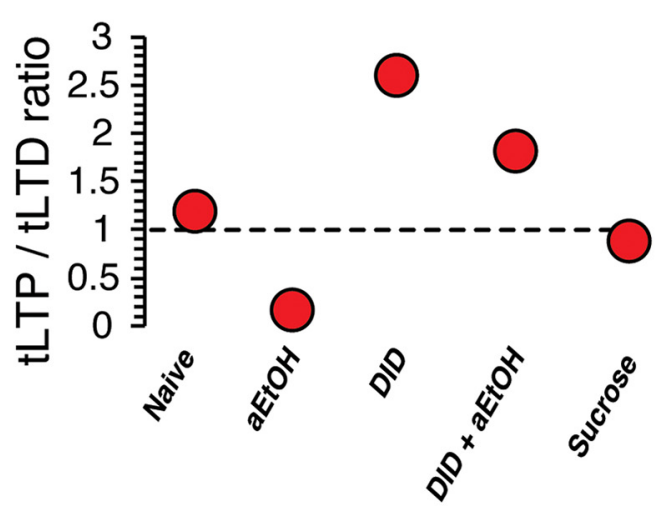

Figure 1. EtOH differentially regulates synaptic plasticity in NAC MSNs from naive and binge-drinking mice. $A$, Light gray traces show 30 overlapping consecutive eEPSPs from a representative NAC MSN recorded in a naive mouse. EPSPs were recorded at resting membrane potential $(-86 \mathrm{mV})$ before (control) and after (postinduction) AP- eEPSP pairing. Horizontal dashed lines illustrate the potentiation of the synaptic strength following induction. Solid blue and red traces show averaged eEPSPs before and after induction, respectively. Bottom, From the same neuron, the graph of EPSP amplitude was monitored every $20 \mathrm{~s}$ before and after synaptic plasticity, respectively. Arrowhead indicates the time of induction. Blue and red horizontal bars indicate where the eEPSPs shown at top were recorded. $\boldsymbol{B}$, tLTD recorded in a representative MSN from a naive mouse acutely exposed to EtOH. $\boldsymbol{C}$, Representative tLTP in a slice of tissue from a DID mice. All stimulation artifacts have been truncated for presentation purposes. D, Daily volumes of EtOH consumed over a 2 week period. Each faded colored line represents consumption for an individual mouse. Black solid circles show the average EtOH consumption $(n=15)$. E, Average amplitudes of tLTP (red symbols) and tLTD (black symbols) in various conditions. Numbers of MSNs evoking tLTP and tLTD are indicated above and below symbols. ${ }^{*} p<0.05,{ }^{* *} p<0.01,{ }^{* * *} p<0.001$. $\boldsymbol{F}$, Ratio of the number of MSNs evoking tLTP/tLTD in naive and DID mice in the presence or absence of acute Et0H. Note the predominance of tLTP over tLTD in DID mice. Induct, Induction; Sucr, sucrose. 
a $20 \mathrm{~ms}$ interval at a rate of $1 \mathrm{~Hz}$ for $90 \mathrm{~s}$, as described previously (Ji et al., 2015). For optogenetic experiments, we evoked EPSPs-EPSCs by flashing 1 -ms-long $470 \mathrm{~nm}$ blue light through the light path of a microscope $60 \times$ objective using a high-powered LED (pE-100, CooLED) under the control of the acquisition software (PatchMaster, HEKA Electronik). When examining AMPA/NMDA ratio in voltage-clamp mode, we evoked AMPA-EPSCs at $-70 \mathrm{mV}$ in the presence of $15 \mu \mathrm{M}$ bicuculline (BIC). After blocking AMPA-EPSPs for 3-4 min after $5 \mu \mathrm{M}$ NBQX perfusion, we held membrane potential at $+40 \mathrm{mV}$ to evoke NMDA-EPSCs. We purchased QX-314 from Ascent Scientific, and BIC, ethanol, and NBQX from Sigma-Aldrich.

Two-photon laser scanning calcium imaging. We filled recording pipettes with Fluo5F $(20 \mu \mathrm{M})$ and Alexa Fluor 549 (30 $\mu \mathrm{M}$; Invitrogen). Dendritic locations were determined based on the loading of Alexa Fluor 594 after breaking into the cell (15-25 min). A custom-made two-photon laser scanner (Scientifica) with a Mai Tai HP Ti:Sapphire (SpectraPhysics) laser providing pulses at $<100 \mathrm{fs}$ at $820 \mathrm{~nm}$ was used for imaging. Linescans along each dendritic location were performed using a $60 \times$ (1.0 numerical aperture) objective (Olympus). We recorded activity at various dendritic locations from the soma with clear branch points $\left(1^{\circ}=\right.$ primary, $2^{\circ}=$ secondary, $3^{\circ}=$ tertiary). Calcium transients were acquired using a standardized protocol controlled by ScanImage (Vidrio) that allowed the laser beam to be "parked" between each image capture. We used PatchMaster version 2.15 to evoke theta burst firing patterns in response to $800 \mathrm{pA}$ current injections to drive $\mathrm{Ca}^{2+}$ transients in MSNs. Only cells with a stable resting membrane potential between -82 and $-90 \mathrm{mV}$ were selected for recordings. All experiments were conducted at $32-34^{\circ} \mathrm{C}$. The protocol consisted of three consecutive potentials at a frequency of $5 \mathrm{~Hz}$, with $10 \mathrm{~s}$ intervals, and at 42 frames/s. Fluorescence ratios were calculated based on $\Delta F=F / F_{0}$, where the baseline fluorescence $\left(F_{0}\right)$ was the average of the first 20 frames. Three responses were averaged and then smoothed using Savitzky-Golay (first-order polynomial, 15 point) filtering to acquire the individual calcium traces for each dendritic location. Slope of the rise of the signal was calculated as shown in Figure 5C. Correlative comparisons between dendritic locations were calculated based on the percentage of the difference between EtOH-naive dendrites and DID dendrite/DID dendrite. Maximum amplitude of the signal was captured for each calcium trace, within a limited response window of 15 frames following the baseline fluorescence. All analysis was conducted using custom-written code in MATLAB.

Analysis of timing-dependent LTP and timing-dependent LTD. We compared the maximum amplitude of EPSPs measured in a $20 \mathrm{~ms}$ time window $10 \mathrm{~ms}$ before and after the onset of the stimulus. We performed this measurement on 30 consecutive EPSPs before and $20 \mathrm{~min}$ after AP-EPSP pairing to smooth out the natural variability in the amplitude of EPSPs. We expressed the difference of EPSP amplitude before and after induction as a percentage of control (100\%). Statistical analysis of EPSC and action potential properties in naive and DID mice was performed with a two-tailed $t$ test and of calcium transients with the MannWhitney test in Prism 7 (GraphPad). For experiments comparing STDP in various alcohol exposures, we used a one-way ANOVA and Bartlett's post hoc test. For experiments comparing STDP in dopamine D1 receptors $[\mathrm{D} 1 \mathrm{R}(+)]$ and dopamine D2 receptors $[\mathrm{D} 1 \mathrm{R}(-)]$ MSNs, we used a two-way ANOVA and a post hoc Bonferroni's multiple-comparison analysis to test statistical significance when comparing the magnitude of STDP in multifactorial experimental conditions. All averaged results are expressed as the mean \pm SEM. In all tests, $p$ values $<0.05$ were considered to be statistically significant.

\section{Results}

Binge alcohol drinking affects both timing-dependent LTP and timing-dependent LTD in core accumbens medium spiny neurons

In naive mice, pairing of AP and electrically-driven EPSP (eEPSP) evoked tLTP (Fig. $1 A, E$, Naive, red symbol) and tLTD (Fig. 1E, black symbol) in equal proportion, confirming previous results (Ji and Martin, 2012). Figure $1 A$ shows representative tLTP in a naive mouse MSN. In fresh slices of tissue from naive mice acutely exposed to $20 \mathrm{~mm} \mathrm{EtOH}$, a concentration typically reached during binge alcohol drinking (Hwa et al., 2011), not only was tLTP nearly totally inhibited but EtOH now favored tLTD as the dominant form of synaptic plasticity [acute EtOH $(\mathrm{aEtOH})$; Fig. $1 B, E]$, as previously reported in the same brain region (Ji et al., 2015). To test whether a history of binge alcohol drinking affected synaptic plasticity in core NAc MSNs, we exposed mice to ethanol daily for 2 weeks using the DID protocol. During this period, ethanol consumption escalated during the first week before reaching a plateau of $\sim 7 \mathrm{~g} / \mathrm{kg}$ ethanol (Fig. $1 D$ ). In contrast to our observations in naive mice, $24 \mathrm{~h}$ following the last drinking bout, we recorded tLTP in a majority of MSNs (Fig. $1 C, E$, DID). Interestingly, when slices from DID mice were acutely exposed to $20 \mathrm{~mm}$ aEtOH, tLTP was still observed in most MSNs (Fig. 1E, DID + aEtOH), although its amplitude appeared smaller compared with that of naive mice. Averaging values in these various experimental conditions confirmed these initial observations $\left(F_{(3,32)}=5.58 ; p=0.0034\right)$. Thus, in naive mice, nearly $50 \%$ of all MSNs tested evoked tLTP with an average amplitude of $144.4 \pm 8.9 \%$ of control ( $n=11$; Fig. $1 E$, Naive) while tLTD was induced in the other half ( $n=9$, Fig. $1 E$, Naive) with an amplitude of $81.2 \pm 2.4 \%$ of control (Fig. 1E). In the presence of acute EtOH in naive mice, tLTP was nearly totally inhibited while tLTD remained unaffected (Fig. $1 E$, aEtOH). In DID mice, while the amplitude of tLTD $(78.9 \pm 5.8 \% ; n=5)$ was comparable $(p=$ $0.73)$ to that of naive mice, LTP $(117.6 \pm 4.3 ; n=13)$ was significantly smaller than that of naive mice $(p=0.026$; Fig. $1 E)$. In DID mice, cells re-exposed to $20 \mathrm{~mm}$ acute EtOH did not demonstrate inhibition of tLTP as it did in naive mice (Fig. 1E), which is indicative of the development of tolerance. Although it did moderately reduce tLTP amplitude $(115.3 \pm 3.4 \% ; n=10)$ compared with that of DID mice, the difference was not significant. Finally, to test whether the pharmacological or rewarding properties of EtOH were responsible for this effect, in the DID behavioral paradigm we replaced $\mathrm{EtOH}$ with sucrose, another naturally occurring rewarding drug (Schneider, 1989; Conover and Shizgal, 1994). Our results indicate that 2-3 weeks of drinking a sucrosebased solution did not alter tLTP/tLTD parity $(n=15$; Fig. $1 E, F)$, mimicking results obtained in naive mice. To quantify the apparent shift toward tLTP in DID mice, we calculated the ratio of the number of MSNs expressing tLTP over tLTD. Figure $1 F$ shows that in naive and sucrose-drinking mice, the ratio was close to 1 , pointing to an equal probability of evoking tLTP and tLTD. However, in DID mice, the ratio shifted markedly toward tLTP, indicating that the parity between ILTP and tLTD observed in naive mice now favored tLTP (Fig. $1 F$ ). This result suggests that the shift of tLTP/tLTD ratio is likely due to the pharmacological properties of $\mathrm{EtOH}$ rather than to its rewarding properties. This set of experiments demonstrates that STDP adapts to binge alcohol drinking by shifting plasticity to a form of tLTP that developed tolerance to the drug.

\section{The switch to tLTP in DID mice occurred at all glutamatergic afferents}

In a recent study, we showed that plasticity at glutamatergic inputs to core NAc MSNs in naive mice presented key differences based on their origin (Ji et al., 2015). While both tLTP and tLTD were present at amygdaloid and hippocampal inputs, only tLTD was found at cortical synapses. We tested whether the shift in synaptic plasticity observed with EPSPs evoked with electrical stimulation in DID mice presented differences based on the origin of the inputs. We injected pAAV9-CaMKIIa-hChR2(H134R)-EYFP into the PFCx, amygdaloid, and hippocampal regions separately 

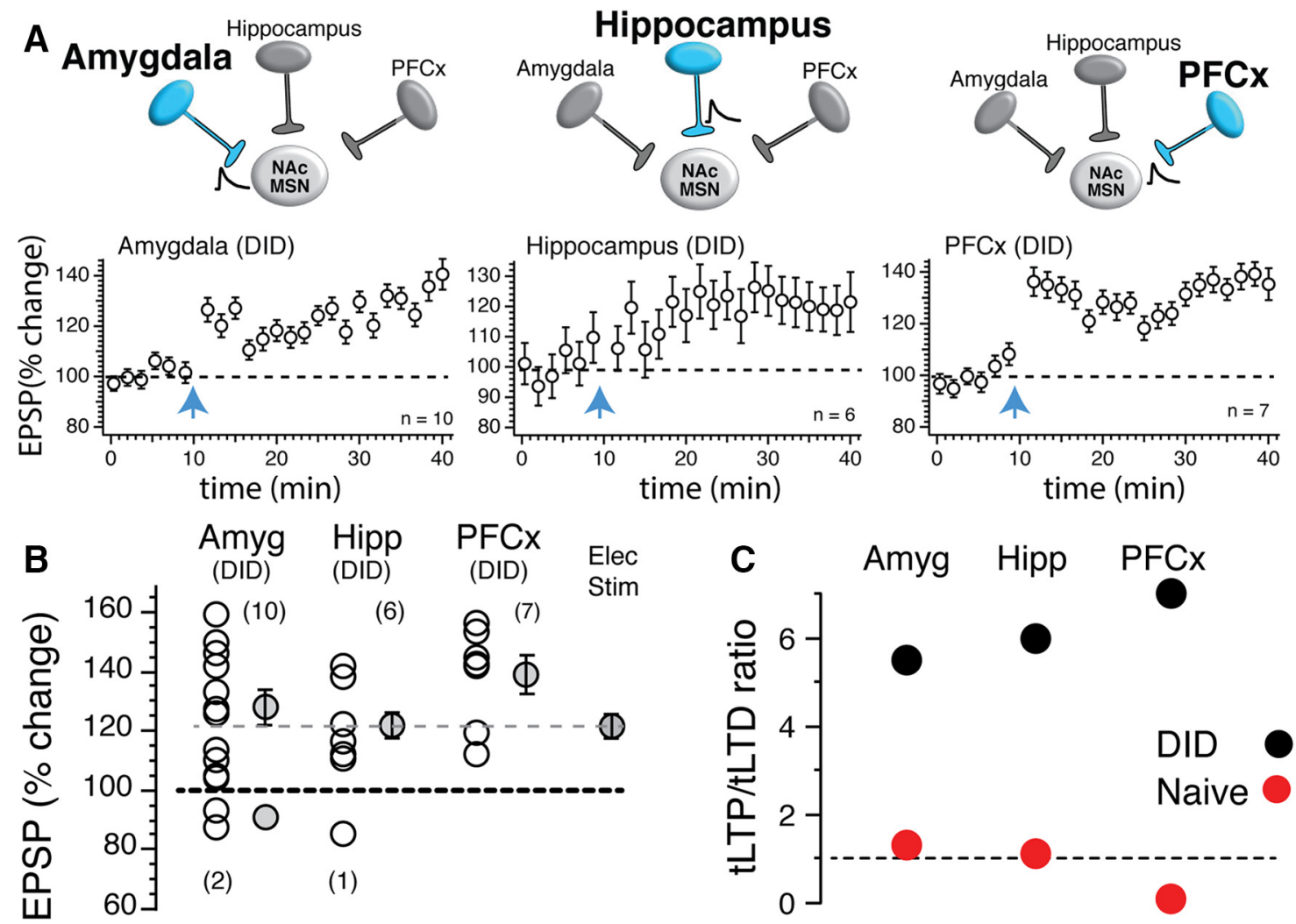

Figure 2. Modulation of synaptic plasticity on optogenetically evoked EPSPs (oEPSPs) at various glutamatergic inputs to MSNs following binge alcohol drinking. $A$, Average amplitude of oEPSPs before and after AP- 0 EPSP pairing (blue arrows) at amygdaloid, hippocampal, and cortical inputs. Schematics above the graphs illustrate the specificity of synaptic responses from the injections of AAV9-ChR2 into one brain region at a time. $B$, Each symbol indicates a change in oEPSP amplitude, evoked by stimulating selectively the amygdaloid, hippocampal, and cortical pathways, measured 20 min after induction in individual MSNs from DID mice. Symbols above and below the black dashed line show $L L T P$ and LLTD, respectively. Changes in synaptic strength after induction are expressed as the percentage of control (100\%). The total number of MSNs recorded in each experimental condition is indicated below the symbols. For comparison, we are showing the average tLTP evoked in DID mice with electrical stimulation (Elec Stim, gray dashed line). C, Ratio of the number of MSNs evoking tLTP/tLTD in DID mice at cortical, hippocampal, and amygdaloid glutamatergic inputs. Amyg, Amydala; Elec Stim, electrical stimulation; Hipp, hippocampus.

(Fig. $2 A$, top panels). As with STDP electrically evoked, the tLTP/ tLTD ratio at all synapses increased markedly: 5.3 and 5.9 at amygdaloid and hippocampal inputs, respectively (Fig. 2C), which represented a dramatic shift from the ratios recorded at the same synapses in naive mice (Fig. $2 C$, solid red circles; Ji et al., 2015). At PFCx synapses, while no tLTP was observed in naive mice (Ji et al., 2015), only this form of plasticity was recorded in DID mice ( $n=7$; Fig. $2 A$, PFCx). A two-tailed $t$ test comparison of the optogenetically driven STDP amplitude in naive (Ji et al., 2015) and DID mice at cortical and hippocampal synapses showed a significant shift toward tLTP (two-tailed $t$ test, $t_{(13)}=$ $6.72, p<0.0001$ and $t_{(17)}=2.44, p=0.033$, respectively). Although we observed a similar trend at amygdala synapses in DID mice compared with naive mice, the difference was not significant $(p=0.08)$. In addition to this shift, tLTP amplitude was reduced compared with that of naive mice, ranging from $123.4 \pm 4.6 \%$, to $128.1 \pm 6 \%$, to $138.6 \pm 6.3 \%$ of control at hippocampal, amygdaloid, and cortical inputs, respectively (Fig. $2 A$ ), although this reduction was not significant. Finally, in DID mice, the magnitude of light-driven tLTP evoked is very similar to the electrically driven tLTP (Fig. 2B, Elec Stim), suggesting that the optogenetic approach did not introduce a bias.

To test whether changes in the basic properties of the glutamatergic synaptic transmission were associated with the shift of STDP, we first examined the probability of glutamate release using the paired-pulse ratio (PPR) protocol by measuring paired
AMPA currents evoked at different intervals at a holding potential of $-70 \mathrm{mV}$ and calculating the EPSCs2/EPSCs1 ratio (P2/P1). As in naive mice, the ratio increased steadily with increasing intervals across all synapses. However, at amygdaloid inputs (Fig. $3 A$, red traces) and hippocampal inputs (Fig. $3 A$, blue traces), the PPR was significantly smaller in DID mice compared with naive mice (Fig. $4 B$, open symbols). Interestingly, we observed no clear changes at cortical inputs (Fig. $3 A$, right). To determine whether binge alcohol drinking altered AMPA and NMDA receptor subunit composition, we studied their deactivation kinetics. Figure $3 C$ presents representative AMPA-EPSCs evoked at cortical, amygdaloid, and hippocampal inputs, whose decay was best fitted with a single exponential (red lines). Comparison of the current deactivation kinetics between naive and DID mice revealed no significant changes (Fig. 3D). Similarly, we found that the deactivation rates of NMDA currents were statistically unchanged in DID mice compared with naive mice (Fig. $3 E, F$ ) at all three synapses.

Because an increase in the number of AMPA receptors is thought to underlie tLTP (Huganir and Nicoll, 2013), we measured the AMPA/NMDA ratio, an index of changing AMPA receptor expression, at all three glutamatergic inputs. Figure $4 \mathrm{~A}$ shows representative AMPA and NMDA currents recorded at the three inputs in DID mice. In naive mice, the AMPA/NMDA ratio was $2.6 \pm 0.28(n=22), 2.51 \pm 0.13(n=11)$, and $4.25 \pm 1.04$ $(n=12)$, at PFCx, amygdaloid, and hippocampal synapses, respectively. In DID mice, it increased markedly at the first two inputs to $6.4 \pm 1.26(n=15)$ and $5.3 \pm 0.54(n=18)$, respec- 
A

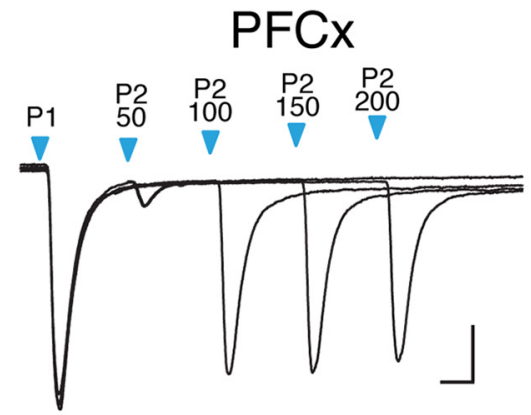

B

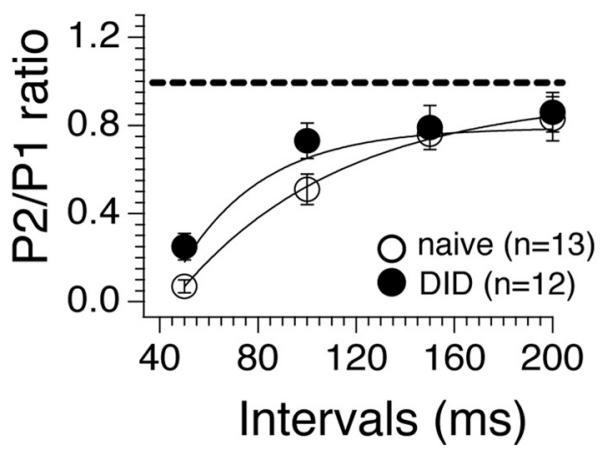

Amygdala

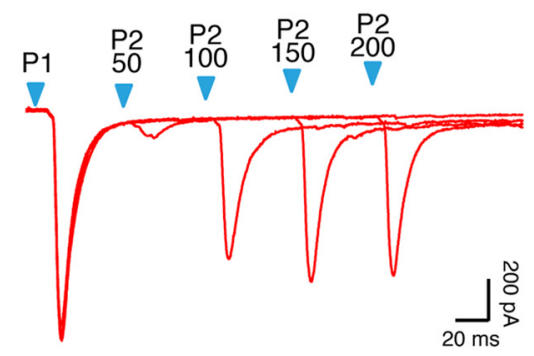

Hippocampus

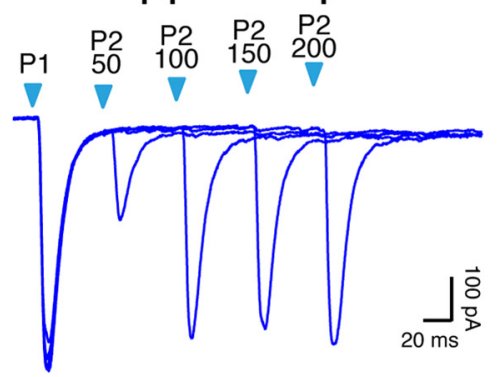

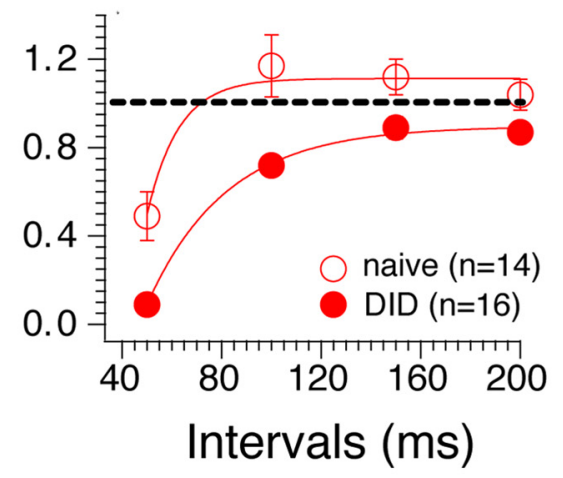
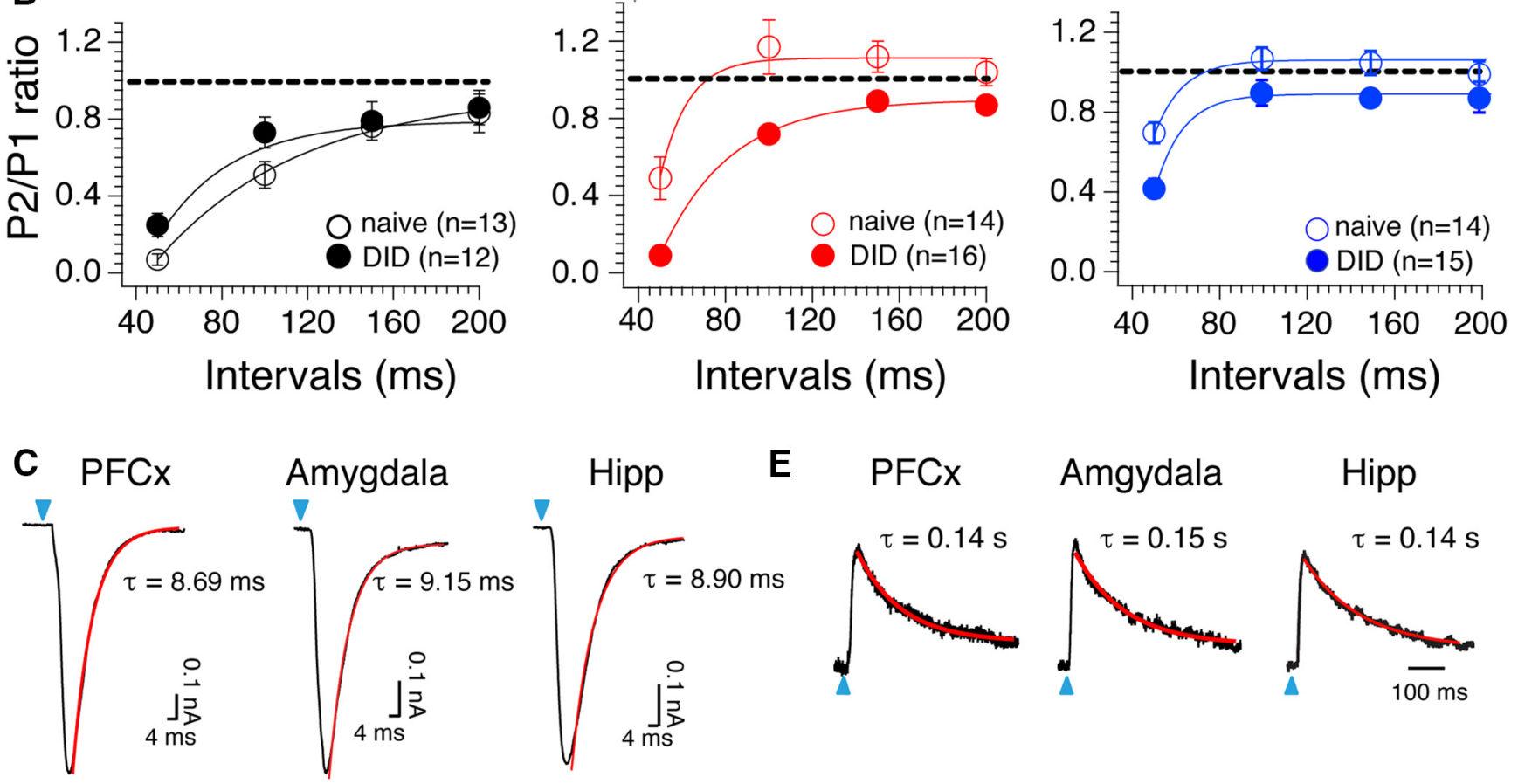

E PFCx

Amgydala

Hipp

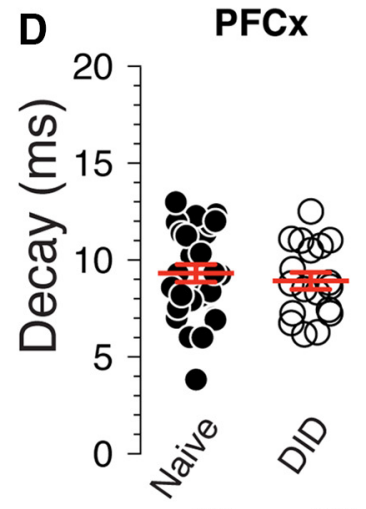

(27)

Amgydala
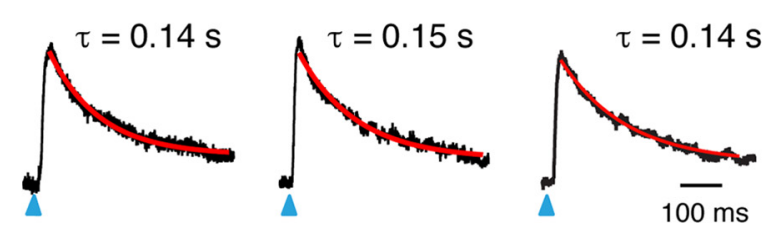

Hipp

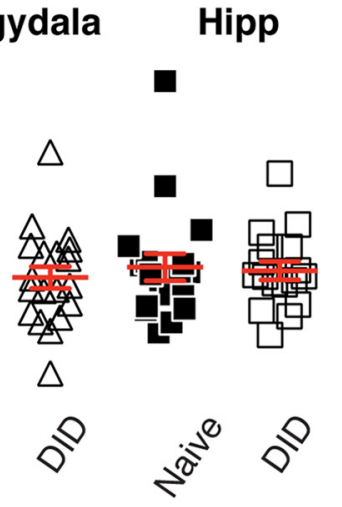

(19)

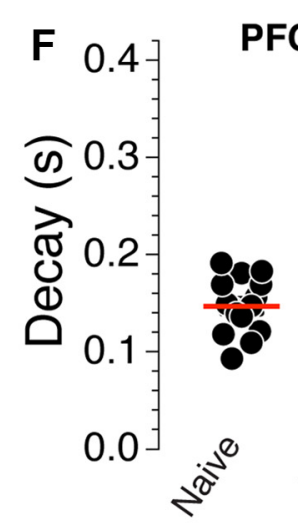

(16)
PFCx

Amgydala

Hipp

Figure 3. Binge alcohol drinking alters optogenetically driven glutamate release probability but not AMPA and NMDA receptor kinetics. $A$, Representative overlapping individual traces of paired AMPA currents recorded at $-70 \mathrm{mV}$ in the presence of $15 \mu \mathrm{m}$ BIC at different intervals from 50 to $200 \mathrm{~ms}$ following stimulation of cortical (black traces), amygdaloid (red traces), and hippocampal (blue traces) pathways. Blue arrowheads show the onset of paired light stimulations. The numbers above indicate the intervals between first and second stimulations. $B$, Average P2/P1 AMPA current ratio at various intervals. ${ }^{*} p<0.05$ and ${ }^{* *} p<0.01$ show statistical significance. The number of neurons recorded in each condition is indicated in parenthesis. $\boldsymbol{C}$, Representative light-evoked AMPA-EPSCs recorded at $-70 \mathrm{mV}$ at cortical, amygdaloid, and hippocampal synapses. Each EPSC was fitted with a single exponential (red line) whose values are shown next to traces. $D$, Distribution of the EPSC deactivation rates in naive and DID mice at cortical, amygdaloid, and hippocampal inputs. No significant differences were measured between naive and DID mice. Solid red bars show the mean \pm SEM. Each symbol represents an MSN. E, Representative light-evoked NMDA-EPSCs recorded at $+40 \mathrm{mV}$ at cortical, amygdaloid, and hippocampal synapses. Each EPSC was fitted with a single exponential (red line) whose values are shown next to the traces. $\boldsymbol{F}$, Same as $\boldsymbol{D}$ for NMDA currents. No significant differences were measured between naive and DID mice at any of the three inputs. Red vertical bars show SEM and average values. Each symbol represents an MSN. Numbers in parentheses at the bottom of graphs indicate the number of MSNs recorded. Hipp, Hippocampus. 
A

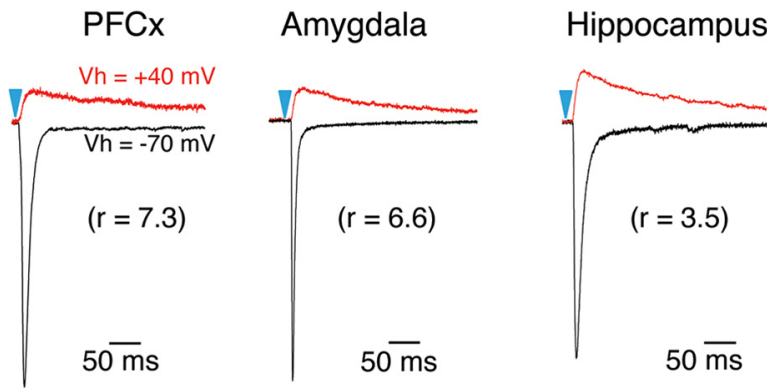

B

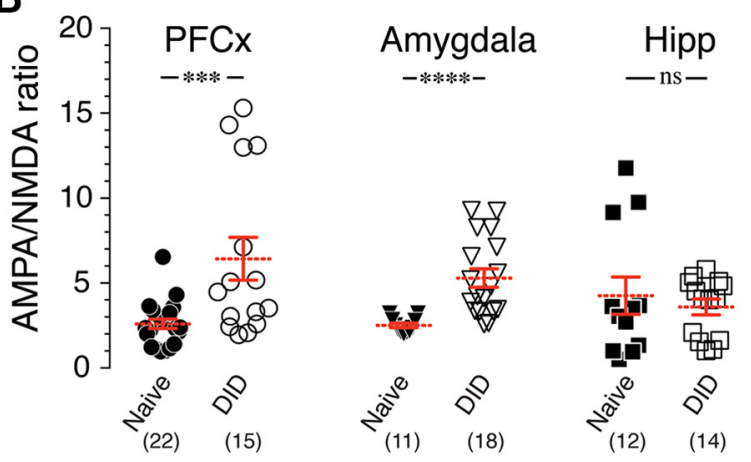

Figure 4. Binge alcohol drinking increases the AMPA/NMDA ratio at cortical and amygdaloid inputs. $A$, Light-evoked AMPA and NMDA traces recorded at $-70 \mathrm{mV}$ (black traces) and +40 $\mathrm{mV}$ (red traces), respectively, in the presence of $15 \mu \mathrm{m} \mathrm{BIC} \mathrm{in} \mathrm{three} \mathrm{representative} \mathrm{MSNs} \mathrm{evoked}$ at cortical ( $\mathrm{PFC}$ ), amygdaloid, and hippocampal inputs. $R$ values below the traces indicate the AMPA/NMDA ratio for each neuron. Blue arrowheads indicate the onset of light stimulation. $B$, Graph of the distribution of the AMPA/NMDA ratio in naive and DID mice at cortical, amygdaloid, and hippocampal inputs. Red solid and dotted bars show the SEM and mean values. Each symbol represents an MSN. The numbers of MSNs recorded are shown in parentheses at the bottom of the graph. Hipp, Hippocampus.

tively. Surprisingly, it decreased modestly at hippocampal synapses $(3.6 \pm 0.5 ; n=14)$. Statistical analysis showed that the ratio increase observed at PFCx and amygdaloid inputs was significant (two-tailed $t$ test, $t_{(35)}=3.51, p=0.0012$ and $t_{(27)}=3.98, p=$ 0.0005 , respectively), unlike the small drop at hippocampal inputs $(p=0.46)$. These results suggest that alterations of synaptic plasticity in DID mice are unlikely to be due to changes in the properties of the glutamatergic synaptic transmission.

\section{Binge alcohol drinking attenuates calcium transients in dendrites of NAc MSNs}

While our data suggest that binge alcohol drinking controls tLTD induction, how the former influences the latter was unclear. Having previously shown that AP-driven calcium-induced calcium release during synaptic induction is necessary for tLTD (Ji and Martin, 2012), one putative path connecting EtOH, APs, and tLTD is calcium. We hypothesized that the ability of APs to drive dendritic calcium transients was altered in DID mice. Combining two-photon laser-scanning microscopy with patch-clamp recordings, we measured calcium signals, driven by action potentials evoked somatically (Fig. $5 B$ ), along the dendritic arbor in first-order $\left(1^{\circ}\right)$, second-order $\left(2^{\circ}\right)$, and third-order $\left(3^{\circ}\right)$ dendrites (Fig. 5A). Dendritic calcium signals, a proxy for measuring the strength of back-propagating APs (BAPs), were characterized by a rapid rise followed by a slow decay (Fig. $5 C$ ). In naive mice, the amplitude of calcium transients remained relatively stable, increasing slightly to $112.1 \pm 10.37 \%$ in $2^{\circ}$ dendrites relative to $1^{\circ}$ processes (Fig. $5 D$, red symbols). However, we observed a significant decline in $3^{\circ}$ dendrites as the calcium signal dropped to 57.4
$27 \pm 7.08 \%$ (Fig. $5 D$, green symbols). Statistical analysis revealed a significant difference between $2^{\circ}$ and $3^{\circ}$ dendrites (MannWhitney $U$ test $=54, z=1.998 p=0.0228)$ and $1^{\circ}$ and $3^{\circ}$ dendrites (Mann-Whitney $U$ test $=60, z=2.091, p=0.0182$ ) only. In DID mice, although the calcium signal similarly decreased between the $1^{\circ}$ and $3^{\circ}$ dendrites, the drop of amplitude was already detectable in $2^{\circ}$ dendrites compared with $1^{\circ}$ dendrites $(65.94 \pm 2.04 \%$; Fig. $5 E)$, an effect that was significant (MannWhitney $U$ test $=150, z=4.517, p<0.0001$ ), unlike in naive mice (Mann-Whitney $U$ test $=120, z=0.681, p=0.247$ ). In comparing these peak calcium transients, we found the values of the $1^{\circ} \mathrm{EtOH}$-naive dendritic response to be $16.4 \%$ greater than that of DID mice, while the EtOH-naive $2^{\circ}$ and $3^{\circ}$ indicated a more prominent difference $\left[2^{\circ}, 23.3 \%\right.$ greater $(p=0.098) ; 3^{\circ}$, $35.7 \%$ greater $(p=0.081)]$. The amplitude of calcium transients further declined in $3^{\circ}$ processes $(51.34 \pm 10.47 \%$; Fig. $5 E$, green symbols; $p<0.0001)$. The slope of the mean decay $[(\Delta F / F) / \Delta t]$ in EtOH-naive mice were found to also exceed that of the DID where the values are as follows: naive $\left(1^{\circ}, 2.83 \pm 0.64 \mathrm{~s} ; 2^{\circ}, 1.81 \pm\right.$ $\left.0.32 \mathrm{~s} ; 3^{\circ}, 0.96 \pm 0.22 \mathrm{~s}\right) ; \mathrm{DID}\left(1^{\circ}, 2.41 \pm 0.31 \mathrm{~s} ; 2^{\circ}, 1.46 \pm 0.15 \mathrm{~s}\right.$; $\left.3^{\circ}, 0.71 \pm 0.11 \mathrm{~s}\right)$. Interestingly, attenuation of calcium transients (Fig. $5 F$, gray area) in $2^{\circ}$ dendrites (Fig. $6 F$, red line) in DID mice was mostly observed in MSNs, where calcium transients were stronger in $1^{\circ}$ dendrites (gray area). Also, the latency between APs and calcium signal onsets in naive and DID mice indicates that changes in the amplitude of calcium signals are unlikely to be the result of transients being recorded at different distances from the soma (data not shown). These data indicate that a faster decay of the dendritic calcium signal may be one of the cellular mechanisms responsible for the loss of tLTD in binge alcohol-drinking mice.

\section{Dopamine receptors modulate STDP differently in MSNs from the direct and indirect pathways}

NAc MSNs are typically classified as belonging to the direct or indirect pathways based on whether they express dopamine D1 or D2 receptors, respectively (Alexander and Crutcher, 1990; Gerfen et al., 1995; Gerfen and Surmeier, 2011). The idea that a drug of abuse like cocaine exerts different effects on the two MSN subpopulations has been supported by a number of studies (Volkow et al., 2009; Ersche et al., 2012; Bock et al., 2013; Creed et al., 2016). However, whether binge alcohol drinking also differentially affects $\mathrm{D} 1 \mathrm{R}(+)$ and $\mathrm{D} 1 \mathrm{R}(-)$ MSNs is unknown. To test this idea, we electrically evoked EPSPs and measured STDP in both $\mathrm{D} 1 \mathrm{R}(+)$ and putative $\mathrm{D} 2 \mathrm{R}(\mathrm{D} 1(-))$ MSNs from naive and DID D1r.Td-tomato mice. Two-way ANOVA revealed a significant main effect of D1 antagonist $\left(F_{(1,38)}=22.38, p<0.0001\right)$, but not of chronic alcohol ingestion (i.e., DID), and a significant D1R antagonist $\times$ alcohol interaction $\left(F_{(1,38)}=15.26 ; p=\right.$ $0.0004)$. Surprisingly, in naive mice, the AP-EPSP pairing evoked tLTD in a majority of neurons (i.e., 9 of 13 neurons; Fig. $6 \mathrm{~A}$, Naive) with a mean amplitude of $91.5 \pm 5.1 \%$ of control $(n=$ $13)$, an effect that was not significantly affected $(p>0.99)$ by the presence of $4 \mu \mathrm{M} \mathrm{SCH} 23390$, a specific $\mathrm{D} 1 \mathrm{R}(+)$ antagonist. Indeed, in this condition, we still recorded tLTD in a majority of MSNs (9 of 11 MSNs; Fig. 6A, Naive + SCH) with a mean amplitude of $87.1 \pm 6.6 \%(n=11)$. However, 2 weeks of binge alcohol drinking significantly altered the response of $\operatorname{D1R}(+)$ MSNs to the pairing induction protocol $(p=0.025)$. Thus, most MSNs switched to tLTP (Fig. 6A, DID; $111.2 \pm 5.6 \% ; n=11$ ). Additionally, the shift to tLTP in DID mice was totally and significantly $(p=0.0001)$ reversed in the presence of SCH23390 (Fig. 6A, DID + SCH) as all MSNs reverted to a robust tLTD 
$(66.05 \pm 2.3 \%$ of control; $n=7)$. The graph in Figure $6 B$ illustrates the shift of the tLTP/tLTD ratio in various experimental conditions. In $\mathrm{D} 1 \mathrm{R}(-)$ MSNs, a similar two-way ANOVA revealed a significant main effect of the alcohol treatment $\left(F_{(1,36)}=5.42, p<0.0425\right)$, but not of D2R antagonist, and a significant D2R antagonist $\times$ alcohol interaction $\left(F_{(1,38)}=\right.$ $22.1 ; p=0.0001)$. In naive mice, APEPSP pairing evoked tLTP in 9 of 11 MSNs (Fig. 6C, Naive). The mean STDP amplitude measured by pooling all MSNs $(n=11)$ was $123.3 \pm 7.5 \%$ of control, an effect that was totally and significantly $(p=0.0016)$ reversed by $1 \mu \mathrm{M}$ sulpiride, a specific D2R antagonist (Fig. 6C, Naive + Sulp; $81.7 \pm 4.4 \%$ of control; $n=10$ ). In DID mice, tLTP was blocked but no shift to tLTD was observed, with an overall effect showing no significant change of the synaptic strength compared with preinduction levels (102 $\pm 4.4 \%$ of control; $n=$ 8; Fig. $6 C$, DID; $p=0.45)$. Exposing slices from DID mice to sulpiride restored tLTP (128.7 $\pm 9.5 \%$ of control; $n=10$; Fig. $6 C$, DID + Sulp). However, this effect was not significant compared with STDP in DID alone $(p=0.071)$. The graph in Figure $6 D$ illustrates the shift of tLTP/tLTD ratio in various experimental conditions in DID mice. These results highlight the different roles of $\mathrm{D} 1 \mathrm{R}$ and $\mathrm{D} 2 \mathrm{R}$ in regulating the effects of binge alcohol drinking on the core accumbens synaptic plasticity.

Having previously shown that TLTD is a form of plasticity that is controlled by BAPs (Ji and Martin, 2012), and in light of the faster decay of transient calcium signals in dendrites of DID mice (Fig. 5), we wondered whether the switch to ILTP in $\mathrm{D} 1 \mathrm{R}(+)$ MSNs was caused by the changing of action potential properties by repeated alcohol exposure. To address this question, we compared the amplitude, width, threshold, and afterhyperpolarization (AHP) of the first action potential of a train evoked by the injection of a $300 \mathrm{pA}$ and 800-ms-long depolarizing current pulse in $\operatorname{D1R}(+)$ and $\operatorname{D1R}(-)$ MSNs from naive and DID mice (Fig. $7 A)$. Thus, the overshoots of $\mathrm{D} 1 \mathrm{R}(+) \mathrm{MSN}$ in naive and DID mice were $35.5 \pm 1.8 \mathrm{mV}(n=$ $21)$ and $32.4 \pm 1.6 \mathrm{mV}(n=18$; Fig. $7 B)$, respectively. The thresholds were $41 \pm 3.2$ and $44 \pm 3.3 \mathrm{mV}$ (Fig. $7 B$, bottom graph), while the widths were $4 \pm 0.8$ and $3.5 \pm 0.8$ $\mathrm{ms}$ in naive and DID mice, respectively (Fig. $7 C$ ). Finally, the action potential AHPs were $10.3 \pm 1.2$ and $10.7 \pm 0.9 \mathrm{mV}$ (Fig. $7 C$, bottom graph). Although we observed overall no clear changes in these parameters in DR1 (-) MSNs between naive and DID mice, we did find a small significant increase of the overshoot (two-tailed $t$ test: $t_{(47)}=2.33 ; p=0.023$ ) from $33.1 \pm 1.4$ $\mathrm{mV}(n=27)$ in naive mice to $37.9 \pm 1.6 \mathrm{mV}(n=21)$ in DID
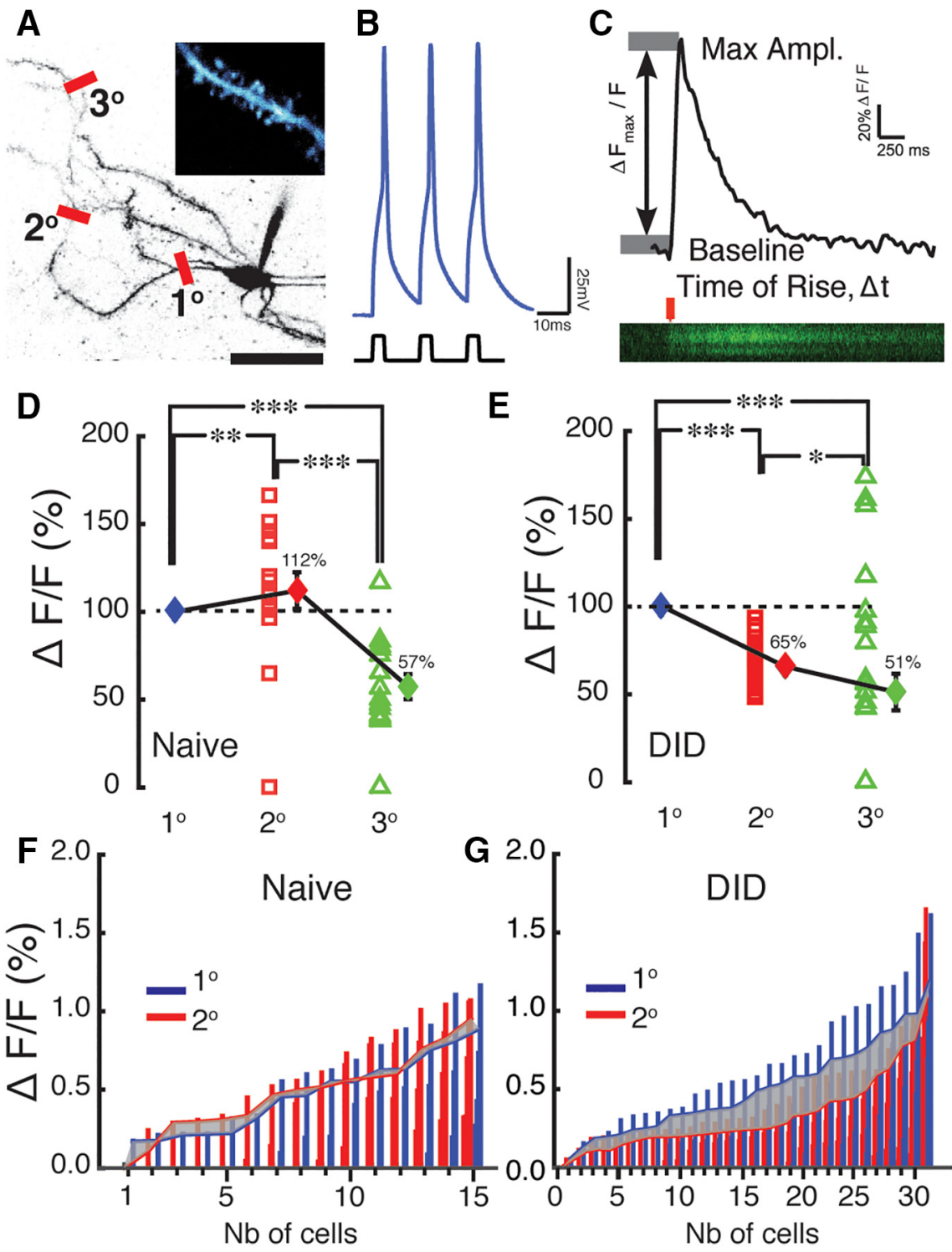

Figure 5. Binge alcohol drinking attenuates the amplitude of calcium transients in $2^{\circ}$ dendrites of NAc MSNs. $\boldsymbol{A}$, Maximum intensity projection of soma and dendritic areas in an MSN. Red lines indicate the approximate dendritic sites $\left(1^{\circ}=\right.$ primary; $2^{\circ}=$ secondary; $3^{\circ}=$ tertiary) where $\mathrm{Ca}^{2+}$ transients were measured as photon laser-scanning microscopy linescans for each MSN, which were visualized using Alexa Fluor 594. Scale bar, $30 \mu \mathrm{m}$. $\boldsymbol{B}$, Representative theta burst firing pattern in response to the 800 pA current injections used to drive the $\mathrm{Ca}^{2+}$ transients in MSNs (resting membrane potential $=-85 \mathrm{mV}$ ). $C$, A representative raw $\mathrm{Ca}^{2+}$ trace from three linescans from a $2^{\circ}$ dendritic site expressed as $\Delta F_{\max } / F$. Calculations for rising slope and maximum amplitude were based on the $t$ value and the average of the baseline signal. $\boldsymbol{D}, \boldsymbol{E}$, Amplitude of $\mathrm{Ca}^{2+}$ transients in $2^{\circ}$ (red symbols) and $3^{\circ}$ dendrites (orange symbols) normalized to calcium responses measured in $1^{\circ}$ dendrites (100\%; blue symbols) in naive and DID mice, respectively. Each symbol represents a neuron. $F, G$, Maximum amplitude of $\mathrm{Ca}^{2+}$ responses from $1^{\circ}$ (blue) and $2^{\circ}$ (red) dendrites shown in ascending order in individual cells in naive and DID mice, respectively. The relationship of the $\mathrm{Ca}^{2+}$ signal between primary and secondary dendrites is shown by the solid lines, which represent the average maximum amplitude of the $\mathrm{Ca}^{2+}$ responses of the dendritic locations. The shaded area highlights the incongruity of the $\mathrm{Ca}^{2+}$ signal, which is more pronounced in the larger $\mathrm{Ca}^{2+}$ transients of the $\mathrm{Scn} 4 \mathrm{~b} \mathrm{KO}$ mice compared with control mice, where the transients are closely matched between $1^{\circ}$ and $2^{\circ}$ dendrites. Max Ampl., Maximum amplitude; Nb, number.

mice. These data suggest that the effects of DID on tLTD are unlikely to be due to the direct action of ethanol on somatic action potentials.

\section{Discussion}

$\operatorname{D1R}(+)$ - and D1R(-)-dependent synaptic plasticity in NAc MSNs

Research on synaptic plasticity in the nucleus accumbens over the past decade using tetanic stimulation, which reliably evokes LTP 
A
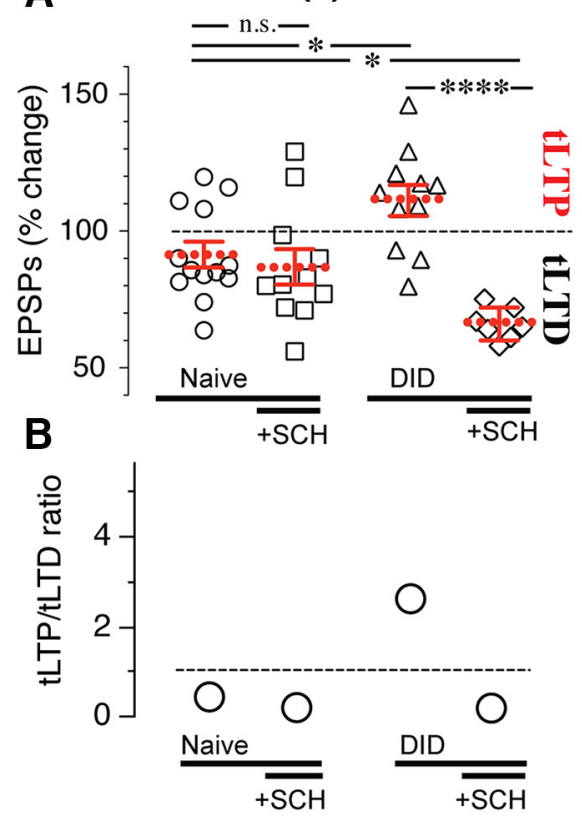

C
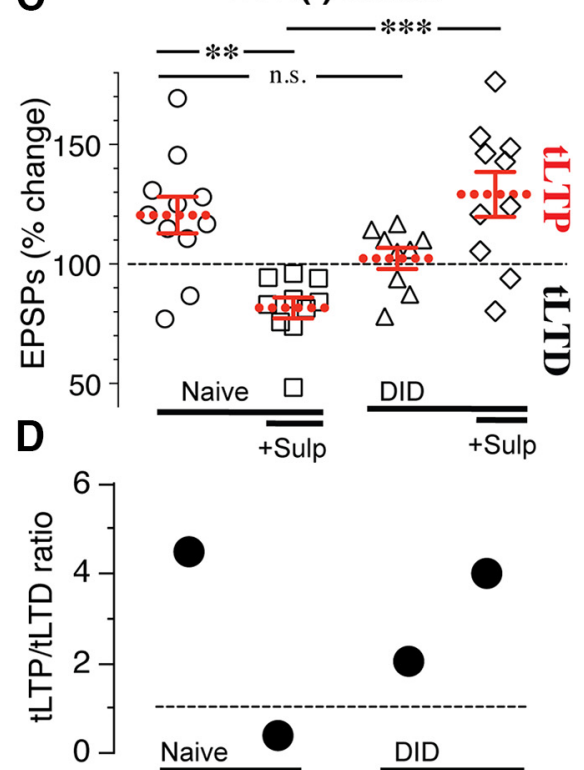
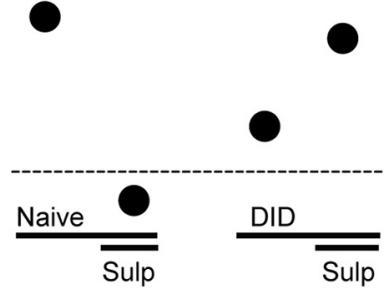

Figure 6. Dopamine receptors control the polarity of synaptic plasticity in MSNs from the direct and indirect pathways. $A$, Each symbol indicates a change of EPSP amplitude 20 min after induction in individual D1R(+) MSNs from naive and DID mice in the presence or absence of D1R antagonist SCH23390. The dotted and solid red lines show mean and SEM values. Symbols above and below the dark dashed line show tLTP and tLTD, respectively. Changes in synaptic strength after induction are expressed as the percentage of control (100\%). $\boldsymbol{B}$, Ratio of the number of MSNs evoking tLTP/tLTD in naive and DID mice in D1R(+) (open circles) and D1R (+) in the presence and absence of SCH23390, the D1R antagonist. $\boldsymbol{C}$, D, Same as for $\boldsymbol{A}$ and $\boldsymbol{B}$ for D1R( - ) MSNs. SCH2390 was replaced with the D2R antagonist sulpiride. ${ }^{*} p<0.05 ;{ }^{* *} p<0.01 ;{ }^{* * *} p<0.001$. Two-way ANOVA and Bonferroni's post hoc test. SCH23390, SCH; Sulp, sulpiride.

at the single-cell level in a great number of brain regions including the dorsal striatum (Kombian and Malenka, 1994; Calabresi et al., 1998; Centonze et al., 2001), failed to achieve the same effect in the NAc. This may stem from the low (i.e., $<4 \mathrm{~Hz}$ ) basal firing rates of all glutamatergic neurons projecting to NAc MSNs (Rosenkranz and Grace, 1999; Margrie et al., 2002; Puig et al., 2003), possibly reflecting biophysical properties that may not be conducive to using high-frequency tetanic stimulation. This has shifted the focus on LTD when studying the cellular and molecular mechanisms responsible for the modulation of synaptic plasticity by drugs of abuse, leaving a number of unanswered questions about LTP and its sensitivity to drugs of abuse, including alcohol. Here we confirmed our initial observation that the same induction paradigm induces both tLTP and tLTD (Ji and Martin, 2012), a surprising result in light of STDP data from the dorsal striatum, a structure having comparable anatomical organization with the NAc. For instance, D1R and D2R MSNs represent $95 \%$ of the total neuronal population and belong to the direct and indirect pathways, respectively (Meredith and Totterdell, 1999). In this region, Fino et al. (2005) showed that STDP with a negative timing (AP-EPSP) induced tLTP, while reversing the pairing order (i.e., EPSP-AP, positive timing) evoked tLTD. Interestingly, other studies reported the opposite results with positive and negative timings evoking tLTP and tLTD, respectively (Pawlak and Kerr, 2008; Shen et al., 2008). Our study in the NAc reveals a different dichotomy in naive mice, with the polarity of plasticity (tLTD vs tLTP) based on whether MSNs are part of the direct versus indirect pathways. The different effects of dopamine on STDP in the dorsal and ventral striatum suggest that this neurotransmitter may be responsible for the unique features of NAc STDP. While the D1R antagonist SCH23390 promotes tLTD in

both the dorsal striatum (Shen et al., 2008) and NAc in naive mice, the D2R antagonist sulpiride appears to have opposite effects by inducing tLTP in the former and tLTD in the latter. Our data show that the ratio of electrically evoked tLTP/ tLTD in unidentified MSNs (Fig. $2 F$ ) and identified MSNs (Fig. 6B,D) is the same (i.e., 2.5), a value that is smaller than that of optogenetically evoked STDP. The inputs that are recruited when evoking eEPSPs may explain the discrepancy between optogenetically and electrically driven STDP. Indeed, Britt et al. (2012) showed that the hippocampal pathway to accumbens shell MSNs could evoke significantly larger EPSCs compared with the amygdaloid and cortical inputs, suggesting that all inputs are not equal, a finding confirmed recently by MacAskill et al. (2014). In light of these observations, it is possible that we preferentially recruited amygdaloid and hippocampal inputs when evoking relatively small electrically driven EPSPs. A different and possibly complementary explanation may stem from another observation by MacAskill et al. (2014), who reported a marked difference between MSNs from the direct and indirect pathways, with the former being less sensitive to ventral hippocampal inputs than the latter. Therefore, an involuntary bias toward one subpopulation of MSNs while recording eEPSPs in unidentified MSNs may compound the discrepancy in the tLTP/tLTD ratio that was observed in our study.

\section{Modulation of STDP in DID mice}

One of the main findings of our study is the differential response of STDP to binge alcohol drinking in $\mathrm{D} 1 \mathrm{R}(+)$ and $\mathrm{D} 1 \mathrm{R}(-)$ MSNs. While tLTD switched to tLTP in D1R(+) MSNs, tLTP was inhibited in D1R(-) MSNs. The switch to tLTP in $\operatorname{DlR}(+)$ MSNs is reminiscent of the effects of alcohol on MSNs in the shell NAc (Jeanes et al., 2011) in a different model of ethanol exposure (i.e., CIE) that is characterized by longer daily bouts of $\mathrm{EtOH}$ vapors (i.e., 16 vs $2 \mathrm{~h}$ for the DID model). In a subsequent study, this group showed that the switch from LTP to LTD was limited to D1R(+) (Renteria et al., 2017). However, a meaningful comparison with our own data is limited for a number of reasons. First, in this study LTD was evoked using a different induction protocol (i.e., pairing EPSPs with a 10-min-long strong depolarization) and was NMDA receptor dependent. This contrasts with tLTD in the core NAc MSN that is NMDA receptor independent and is controlled by BAPs (Ji and Martin, 2012). Also, while Renteria et al. (2017) reported no changes of synaptic strength in D1R(-) MSNs in the shell NAc of naive mice, we found that tLTP was the predominant form of plasticity in DID mice. Therefore, it is likely that LTD and tLTD in naive mice, and their regulation in CIE and DID mice, mobilizes different cellular and molecular mechanisms.

The switch from tLTD to tLTP in D1R(+) MSNs was somewhat surprising considering that ILTP was totally inhibited while tLTD was insensitive to acute EtOH in naive mice (Ji and Martin, 2012). Although input-specific changes in the properties of the 

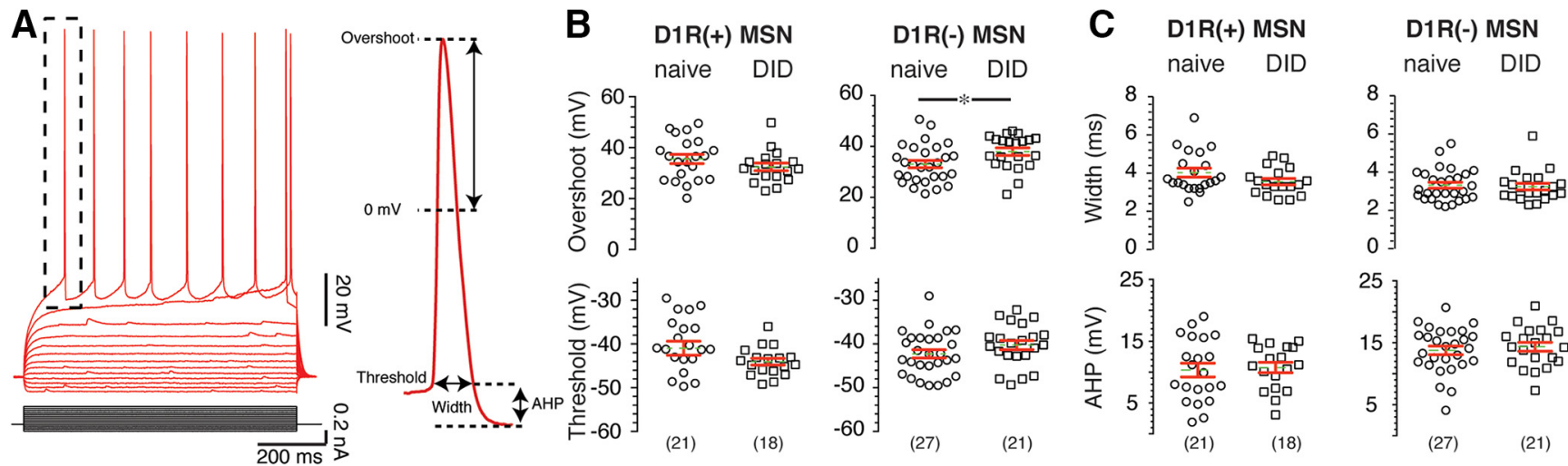

Figure 7. Binge alcohol drinking does not alter action potential properties in D1R $(+)$ and D1R $(-)$ MSNs. $A$, Left, A train of action potentials evoked while acquiring a series of voltage traces (red traces) in response to incrementally larger injected current steps (black traces). Right, The various properties of the first action potential (shown in broken line box, left) of the train that were analyzed in DR1 (+) and D1R( - ) MSNs from naive and DID mice. $\boldsymbol{B}$, Distribution of MSN action potential overshoot (top graphs) and threshold values (bottom graphs) from naive mice (open circles) and DID mice (open square symbols) in D1R(+) (left graphs) and D1R(-) (right graphs). C, Distribution of action potential width and AHP in naive and DID mice. Numbers at the bottom of the graphs show the number of MSNs recorded in each experimental condition.

glutamatergic synaptic transmission may account for this shift, as seen with cocaine in the accumbens (Britt et al., 2012; MacAskill et al., 2014), our data do not seem to support this hypothesis. Alternatively, tLTP may result from a loss of tLTD, resulting from smaller dendritic calcium transients evoked by BAPs in DID mice. However, our data showing no difference in the properties of APs between naive and DID mice rule out the possibility that DID alters somatic action potentials, the electrical event that is at the inception of BAPs. It is more likely that short daily bouts of alcohol regulate the expression of ion channels in dendrites that contribute to action potential backpropagation. There is a large body of evidence showing that action potential backpropagation is an active process that relies on sodium, calcium, and potassium channels (Frick and Johnston, 2005), and that their expression impacts backpropagation and calcium transients (Frick et al., 2004). Therefore, alterations of the expression of dendritic ion channels, their modulation by dopamine, or both in DID mice may account for the attenuated dendritic calcium signals and, by extension, to the loss of tLTD in these mice. It is important to note that changes in dendritic calcium transients are only correlative and do not necessarily fully account for the loss of tLTD in DID mice. Experiments based on the tetanic stimulation paradigm led to the generally accepted view that LTP is associated with fast and large rises of calcium, while smaller and slower calcium transients are thought to be responsible for LTD (Bienenstock et al., 1982; Lisman, 1989; Hansel et al., 1997). As such, one would expect to see a reduction in dendritic calcium transients to target tLTP. Yet, there are potentially two main caveats to this idea. First, it is not clear whether this rule applies to all neuronal types, including the nucleus accumbens MSNs. Second, STDP differs substantially from the more classical tetanic stimulation paradigm as it relies on the precise timing of EPSPs and BAPs, the latter being essential to tLTD induction (Ji and Martin, 2012). Therefore, alterations of BAP-mediated dendritic calcium are likely to impact directly the probability of MSNs to evoke tLTD, as shown here. Additionally, measures of dendritic calcium provide only a partial view of its role in shaping plasticity, a phenomenon that ultimately occurs mostly in spines, and it would be imprudent to draw a direct line between dendritic calcium transients and altered tLTD. Further studies are needed to fully establish the relationship between weaker tLTD and smaller dendritic calcium transients.

In contrast to $\mathrm{D} 1 \mathrm{R}(+) \mathrm{MSNs}$, the failure of $\mathrm{D} 1 \mathrm{R}(-) \mathrm{MSN}$ to evoke tLTP in DID mice suggests that these neurons adapt very differently to repeated EtOH exposures. Although it is unclear what cellular underpinning accounts for the loss of tLTP, it is likely to require an inhibition of calcium signals, the key messenger underlying LTP formation (Raymond and Redman, 2002). Although NMDA receptors may be considered a prime target considering their high permeability to calcium, this is unlikely since the $\mathrm{Ca}^{2+}$ permeabilities of heteromeric NMDA receptor channels are comparable among the four kinds of heteromeric channels (Burnashev et al., 1992; Monyer et al., 1994). Alternatively, the loss of tLTP may stem from AMPA receptors undergoing changes in their subunit composition. Indeed, they are also permeable to calcium, albeit to a lesser extent than NMDA receptors. Thus, DID may cause a switch of the expression of AMPA receptor from the GluR1, a highly calcium-permeable subunit that is expressed in the NAc (Martin et al., 1993; Kondo et al., 2000), to the GluR2 subunits that is nearly impermeable to this cation (Geiger et al., 1995). The decreased expression of GluR1 in the amygdala (Jin et al., 2014b) and the increased expression of GluR2 in the cortical region of individuals with alcoholism (Jin et al., 2014a) attest to the sensitivity of these AMPA receptor subunits to alcohol.

The functional relevance of an overrepresentation of tLTP in $\mathrm{D} 1 \mathrm{R}(+)$ MSNs from DID mice remains unclear. However, studies of behavioral sensitization showed that this mouse model for addiction (Wolf, 1998; Robinson and Berridge, 2000) was linked to LTP (Ungless et al., 2001; Saal et al., 2003), the leading candidate mediating neuronal plasticity. In naive mice, Creed et al. (2016) recently reported that the ventral pallidum integrates converging information from the direct and indirect pathways in the accumbens. In the ventral pallidum, the same stimulation paradigm induces LTP and LTD at GABAergic synapses from NAc direct and indirect pathway, respectively, a reversed image of what we report here at glutamatergic inputs. Importantly, while D1Rs MSN projections to the ventral pallidum are responsible for the reinforcing effects of cocaine, D2R-MSN projections carry their anhedonic properties. This finding further underscores the idea that D1R MSNs and D2R MSNs, possibly through LTP and LTD, encode different facets of addiction. Although EtOH self-administration does not equate with drug sensitization, the parallel with our data suggests that tLTP may be necessary for the development of alcohol drinking. 


\section{References}

Agoglia AE, Holstein SE, Reid G, Hodge CW (2015) CaMKII $\alpha$-GluAl activity underlies vulnerability to adolescent binge alcohol drinking. Alcohol Clin Exp Res 39:1680-1690. CrossRef Medline

Alexander GE, Crutcher MD (1990) Functional architecture of basal ganglia circuits: neural substrates of parallel processing. Trends Neurosci 13:266271. CrossRef Medline

Bienenstock EL, Cooper LN, Munro PW (1982) Theory for the development of neuron selectivity: orientation specificity and binocular interaction in visual cortex. J Neurosci 2:32-48. Medline

Bock R, Shin JH, Kaplan AR, Dobi A, Markey E, Kramer PF, Gremel CM, Christensen CH, Adrover MF, Alvarez VA (2013) Strengthening the accumbal indirect pathway promotes resilience to compulsive cocaine use. Nat Neurosci 16:632-638. CrossRef Medline

Britt JP, Benaliouad F, McDevitt RA, Stuber GD, Wise RA, Bonci A (2012) Synaptic and behavioral profile of multiple glutamatergic inputs to the nucleus accumbens. Neuron 76:790-803. CrossRef Medline

Burnashev N, Schoepfer R, Monyer H, Ruppersberg JP, Günther W, Seeburg PH, Sakmann B (1992) Control by asparagine residues of calcium permeability and magnesium blockade in the NMDA receptor. Science 257: 1415-1419. CrossRef Medline

Calabresi P, Centonze D, Gubellini P, Pisani A, Bernardi G (1998) Blockade of M2-like muscarinic receptors enhances long-term potentiation at corticostriatal synapses. Eur J Neurosci 10:3020-3023. CrossRef Medline

Centonze D, Picconi B, Gubellini P, Bernardi G, Calabresi P (2001) Dopaminergic control of synaptic plasticity in the dorsal striatum. Eur J Neurosci 13:1071-1077. CrossRef Medline

Conover KL, Shizgal P (1994) Competition and summation between rewarding effects of sucrose and lateral hypothalamic stimulation in the rat. Behav Neurosci 108:537-548. CrossRef Medline

Cozzoli DK, Goulding SP, Zhang PW, Xiao B, Hu JH, Ary AW, Obara I, Rahn A, Abou-Ziab H, Tyrrel B, Marini C, Yoneyama N, Metten P, Snelling C, Dehoff MH, Crabbe JC, Finn DA, Klugmann M, Worley PF, Szumlinski KK (2009) Binge drinking upregulates accumbens mGluR5-Homer2PI3K signaling: functional implications for alcoholism. J Neurosci 29: 8655-8668. CrossRef Medline

Cozzoli DK, Courson J, Rostock C, Campbell RR, Wroten MG, McGregor H, Caruana AL, Miller BW, Hu JH, Wu Zhang P, Xiao B, Worley PF, Crabbe JC, Finn DA, Szumlinski KK (2016) Protein kinase C epsilon activity in the nucleus accumbens and central nucleus of the amygdala mediates binge alcohol consumption. Biol Psychiatry 79:443-451. CrossRef Medline

Creed M, Ntamati NR, Chandra R, Lobo MK, Lüscher C (2016) Convergence of reinforcing and anhedonic cocaine effects in the ventral pallidum. Neuron 92:214-226. CrossRef Medline

Duka T, Gentry J, Malcolm R, Ripley TL, Borlikova G, Stephens DN, Veatch LM, Becker HC, Crews FT (2004) Consequences of multiple withdrawals from alcohol. Alcohol Clin Exp Res 28:233-246. CrossRef Medline

Ersche KD, Jones PS, Williams GB, Turton AJ, Robbins TW, Bullmore ET (2012) Abnormal brain structure implicated in stimulant drug addiction. Science 335:601-604. CrossRef Medline

Fino E, Glowinski J, Venance L (2005) Bidirectional activity-dependent plasticity at corticostriatal synapses. J Neurosci 25:11279-11287. CrossRef Medline

Frick A, Johnston D (2005) Plasticity of dendritic excitability. J Neurobiol 64:100-115. CrossRef Medline

Frick A, Magee J, Johnston D (2004) LTP is accompanied by an enhanced local excitability of pyramidal neuron dendrites. Nat Neurosci 7:126-135. CrossRef Medline

Geiger JR, Melcher T, Koh DS, Sakmann B, Seeburg PH, Jonas P, Monyer H (1995) Relative abundance of subunit mRNAs determines gating and $\mathrm{Ca} 2+$ permeability of AMPA receptors in principal neurons and interneurons in rat CNS. Neuron 15:193-204. CrossRef Medline

Gerfen CR, Surmeier DJ (2011) Modulation of striatal projection systems by dopamine. Annu Rev Neurosci 34:441-466. CrossRef Medline

Gerfen CR, Keefe KA, Gauda EB (1995) D1 and D2 dopamine receptor function in the striatum: coactivation of D1- and D2-dopamine receptors on separate populations of neurons results in potentiated immediate early gene response in D1-containing neurons. J Neurosci 15:81678176. Medline

Gibb SL, Hamida SB, Lanfranco MF, Ron D (2011) Ethanol-induced increase in Fyn kinase activity in the dorsomedial striatum is associated with subcellular redistribution of protein tyrosine phosphatase $\alpha$. J Neurochem 119:879-889. CrossRef Medline
Hansel C, Artola A, Singer W (1997) Relation between dendritic Ca2 + levels and the polarity of synaptic long-term modifications in rat visual cortex neurons. Eur J Neurosci 9:2309-2322. CrossRef Medline

Hartley DE, Elsabagh S, File SE (2004) Binge drinking and sex: effects on mood and cognitive function in healthy young volunteers. Pharmacol Biochem Behav 78:611-619. CrossRef Medline

Hendrickson LM, Zhao-Shea R, Tapper AR (2009) Modulation of ethanol drinking-in-the-dark by mecamylamine and nicotinic acetylcholine receptor agonists in C57BL/6J mice. Psychopharmacology (Berl) 204:563572. CrossRef Medline

Huganir RL, Nicoll RA (2013) AMPARs and synaptic plasticity: the last 25 years. Neuron 80:704-717. CrossRef Medline

Hwa LS, Chu A, Levinson SA, Kayyali TM, DeBold JF, Miczek KA (2011) Persistent escalation of alcohol drinking in C57BL/6J mice with intermittent access to 20\% ethanol. Alcohol Clin Exp Res 35:1938-1947. CrossRef Medline

Jeanes ZM, Buske TR, Morrisett RA (2011) In vivo chronic intermittent ethanol exposure reverses the polarity of synaptic plasticity in the nucleus accumbens shell. J Pharmacol Exp Ther 336:155-164. CrossRef Medline

Ji X, Martin GE (2012) New rules governing synaptic plasticity in core nucleus accumbens medium spiny neurons. Eur J Neurosci 36:3615-3627. CrossRef Medline

Ji X, Saha S, Martin GE (2015) The origin of glutamatergic synaptic inputs controls synaptic plasticity and its modulation by alcohol in mice nucleus accumbens. Front Synaptic Neurosci 7:12. CrossRef Medline

Jin Z, Bhandage AK, Bazov I, Kononenko O, Bakalkin G, Korpi ER, Birnir B (2014a) Selective increases of AMPA, NMDA, and kainate receptor subunit mRNAs in the hippocampus and orbitofrontal cortex but not in prefrontal cortex of human alcoholics. Front Cell Neurosci 8:11. CrossRef Medline

Jin Z, Bhandage AK, Bazov I, Kononenko O, Bakalkin G, Korpi ER, Birnir B (2014b) Expression of specific ionotropic glutamate and GABA-A receptor subunits is decreased in central amygdala of alcoholics. Front Cell Neurosci 8:288. CrossRef Medline

Kombian SB, Malenka RC (1994) Simultaneous LTP of non-NMDA- and LTD of NMDA-receptor-mediated responses in the nucleus accumbens. Nature 368:242-246. CrossRef Medline

Kondo M, Okabe S, Sumino R, Okado H (2000) A high GluR1: GluR2 expression ratio is correlated with expression of $\mathrm{Ca} 2+$-binding proteins in rat forebrain neurons. Eur J Neurosci 12:2812-2822. CrossRef Medline

Koob GF (1996) Hedonic valence, dopamine and motivation. Mol Psychiatry 1:186-189. Medline

Lisman J (1989) A mechanism for the Hebb and the anti-Hebb processes underlying learning and memory. Proc Natl Acad Sci U S A 86:95749578. CrossRef Medline

Lum EN, Campbell RR, Rostock C, Szumlinski KK (2014) mGluR1 within the nucleus accumbens regulates alcohol intake in mice under limitedaccess conditions. Neuropharmacology 79:679-687. CrossRef Medline

MacAskill AF, Cassel JM, Carter AG (2014) Cocaine exposure reorganizes cell type- and input-specific connectivity in the nucleus accumbens. Nat Neurosci 17:1198-1207. CrossRef Medline

Margrie TW, Brecht M, Sakmann B (2002) In vivo, low-resistance, wholecell recordings from neurons in the anaesthetized and awake mammalian brain. Pflugers Arch 444:491-498. CrossRef Medline

Martin LJ, Blackstone CD, Levey AI, Huganir RL, Price DL (1993) AMPA glutamate receptor subunits are differentially distributed in rat brain. Neuroscience 53:327-358. CrossRef Medline

Meredith GE, Totterdell S (1999) Microcircuits in nucleus accumbens' shell and core involved in cognition and reward. Psychobiology 27:165-186.

Monyer H, Burnashev N, Laurie DJ, Sakmann B, Seeburg PH (1994) Developmental and regional expression in the rat brain and functional properties of four NMDA receptors. Neuron 12:529-540. CrossRef Medline

Naimi TS, Brewer RD, Mokdad A, Denny C, Serdula MK, Marks JS (2003) Binge drinking among US adults. JAMA 289:70-75. CrossRef Medline

Pawlak V, Kerr JN (2008) Dopamine receptor activation is required for corticostriatal spike-timing-dependent plasticity. J Neurosci 28:2435-2446. CrossRef Medline

Puig MV, Celada P, Díaz-Mataix L, Artigas F (2003) In vivo modulation of the activity of pyramidal neurons in the rat medial prefrontal cortex by 5 -HT2A receptors: relationship to thalamocortical afferents. Cereb Cortex 13:870-882. CrossRef Medline

Raymond CR, Redman SJ (2002) Different calcium sources are narrowly 
tuned to the induction of different forms of LTP. J Neurophysiol 88:249255. Medline

Renteria R, Maier EY, Buske TR, Morrisett RA (2017) Selective alterations of NMDAR function and plasticity in D1 and D2 medium spiny neurons in the nucleus accumbens shell following chronic intermittent ethanol exposure. Neuropharmacology 112:164-171. CrossRef Medline

Rhodes JS, Best K, Belknap JK, Finn DA, Crabbe JC (2005) Evaluation of a simple model of ethanol drinking to intoxication in C57BL/6J mice. Physiol Behav 84:53-63. CrossRef Medline

Roberto M, Nelson TE, Ur CL, Gruol DL (2002) Long-term potentiation in the rat hippocampus is reversibly depressed by chronic intermittent ethanol exposure. J Neurophysiol 87:2385-2397. Medline

Robinson TE, Berridge KC (2000) The psychology and neurobiology of addiction: an incentive-sensitization view. Addiction 95 [Suppl 2]:S91S117. Medline

Rosenkranz JA, Grace AA (1999) Modulation of basolateral amygdala neuronal firing and afferent drive by dopamine receptor activation in vivo. J Neurosci 19:11027-11039. Medline

Saal D, Dong Y, Bonci A, Malenka RC (2003) Drugs of abuse and stress trigger a common synaptic adaptation in dopamine neurons. Neuron 37:577-582. CrossRef Medline

Schneider LH (1989) Orosensory self-stimulation by sucrose involves brain dopaminergic mechanisms. Ann N Y Acad Sci 575:307-319. CrossRef Medline

Schuckit MA (1994) Low level of response to alcohol as a predictor of future alcoholism. Am J Psychiatry 151:184-189. CrossRef Medline

Schuckit MA, Smith TL, Hesselbrock V, Bucholz KK, Bierut L, Edenberg H, Kramer J, Longacre E, Fukukura T, Kalmijn J, Danko GP, Trim R (2008) Clinical implications of tolerance to alcohol in nondependent young drinkers. Am J Drug Alcohol Abuse 34:133-149. CrossRef Medline

Shen W, Flajolet M, Greengard P, Surmeier DJ (2008) Dichotomous dopaminergic control of striatal synaptic plasticity. Science 321:848-851. CrossRef Medline
Silvestre de Ferron B, Bennouar KE, Kervern M, Alaux-Cantin S, Robert A, Rabiant K, Antol J, Naassila M, Pierrefiche O (2015) Two binges of ethanol a day keeps the memory away in adolescent rats: key role for Glun2B subunit. Int J Neuropsychopharmacol 19:pyv087. CrossRef Medline

Stephens DN, Duka T (2008) Review. Cognitive and emotional consequences of binge drinking: role of amygdala and prefrontal cortex. Philos Trans R Soc Lond B Biol Sci 363:3169-3179. CrossRef Medline

Stephens DN, Ripley TL, Borlikova G, Schubert M, Albrecht D, Hogarth L, Duka T (2005) Repeated ethanol exposure and withdrawal impairs human fear conditioning and depresses long-term potentiation in rat amygdala and hippocampus. Biol Psychiatry 58:392-400. CrossRef Medline

Tomsovic M (1974) Binge" and continuous drinkers. Characteristics and treatment follow-up. Q J Stud Alcohol 35:558-564. Medline

Townshend JM, Duka T (2002) Patterns of alcohol drinking in a population of young social drinkers: a comparison of questionnaire and diary measures. Alcohol Alcohol 37:187-192. CrossRef Medline

Ungless MA, Whistler JL, Malenka RC, Bonci A (2001) Single cocaine exposure in vivo induces long-term potentiation in dopamine neurons. Nature 411:583-587. CrossRef Medline

Volkow ND, Fowler JS, Wang GJ, Baler R, Telang F (2009) Imaging dopamine's role in drug abuse and addiction. Neuropharmacology 56 [Suppl 1]: 3-8. CrossRef Medline

Wechsler H, Davenport A, Dowdall G, Moeykens B, Castillo S (1994) Health and behavioral consequences of binge drinking in college. A national survey of students at 140 campuses. JAMA 272:1672-1677. CrossRef Medline

Weissenborn R, Duka T (2003) Acute alcohol effects on cognitive function in social drinkers: their relationship to drinking habits. Psychopharmacology (Berl) 165:306-312. CrossRef Medline

Wolf ME (1998) The role of excitatory amino acids in behavioral sensitization to psychomotor stimulants. Prog Neurobiol 54:679-720. CrossRef Medline 